Mieczysław Celestyn Paczkowski OFM

Uniwersytet Mikołaja Kopernika, Toruń

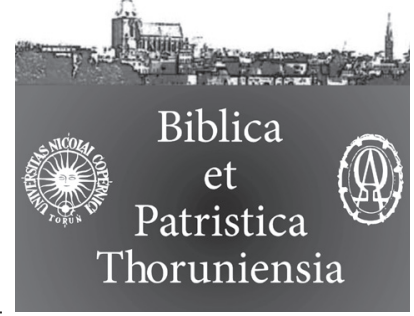

7 (2014) 4 ISSN 1689-5150

DOI: http://dx.doi.org/10.12775/BPTh.2014.024

\title{
Czujny zwiastun brzasku i zmartwychwstania. Kogut w symbolice starochrześcijańskiej
}

\section{Watchful herald of the morning and resurrection. The rooster in the ancient Christian symbolism}

Słowa kluczowe: Kogut (symbol); Biblia; chrześcijaństwo starożytne; język religijny.

Key words: Rooster (symbol of); Bible; Christianity (ancient); religious language.

Streszczenie. Postać koguta stanowi jeden z elementów specyficznego zbioru symboli, należącego nie tylko do chrześcijaństwa, lecz również do innych religii i wielu kultur. W przeszłości kultura europejska chętnie łączyła koguta ze słońcem: swoim pianiem obwieszczał on świt i odpędzał demony mroku. Wyliczano i zauważano niemal wyłącznie same pozytywne cechy koguta. Pismo Święte nie idzie śladem starożytnego świata klasycznego, ale autorzy świętych ksiąg zwrócili uwagę na tak wspaniałe tworzenie Boże. Tradycja żydowska i chrześcijańska posługują się wyrażeniem „o pianiu koguta” (łac. gallicinium), co znaczy bardzo wcześnie rano. Kogut stał się w powszechnej świadomości zwiastunem dnia. Ogłaszanie pianiem nadchodzącego brzasku było dla wierzących w Chrystusa przypomnieniem prawdy o zmartwychwstaniu i wezwaniem do czuwania. Sylwetka koguta na stałe zresztą weszła do ornamentyki i ikonografii. Kogut obwieszczał także nadzieję zmartwychwstania. Podobnie jak ten ptak czuwa, czekając na pierwsze blaski poranka, również chrześcijanie powinni być czujni i gotowi na przyjście Pana. Na kartach Ewangelii pianie koguta to przypomnienie trudnych chwil i zaparcia się Zbawiciela przez Piotra apostoła (por. Mt 26,29-75; Mk 14,53-72; Łk 22,54-71; J 18,12-27). Związek wizerunku koguta ze znanym i komentowanym fragmentem Ewangelii spowodował, że często przedstawiano tego ptaka na mozaikach i lampkach oliwnych. Te ostatnie przedmioty przypominały o potrzebie czuwania i pomagały w nim. W homiletyce chrześcijańskiej kogut stał się także symbolem głoszących słowo Boże. Przez przepowiadania słowa Bożego winno budzić się „drzemiących”, czyli niezbyt gorliwych chrześcijan.

Abstract. The cock belongs to a specific set of symbols that are found not only in Christianity but also in other religions and cultures. In the past, European culture linked the figure of this bird with the sun: the crowing rooster proclaimed the dawn and ban- 
ished the darkness. The Christianity made it a symbol of the victory of light over darkness and the triumph of good over evil. It were noted only the positive features of the rooster. The Holy Scripture does not follow classical antiquity, but the authors of the sacred books were turning their attention to this wonderful creature. The Jewish and Christian traditions make use of the expression „crowing rooster”, which means „very early in the morning" (lat. gallicinium). The cock was then the herald of the day that the believers of Christ remembered the truth of the resurrection and the need to keep watch. The figure of the rooster permanently entered in the ornamentation and Christian iconography. However, it postponed the hope of awakening in eternity. The rooster would signify the repentance of the saint and religious vigilance as well as resurrection. As the rooster watched for the morning, so all Christians were to watch for the Lord who would one day suddenly return to judge the living and the dead. The bird in question remembered also the difficult time of the Apostle Peter's denial (see Mt 26:29-75: Mk 14:53-72; Lk 22: 54-71; J 18:12-27). For this reason this Gospel passage, known and frequently commented, was represented on the mosaics and oil lamps. These tools remembered the need for vigilance on the part of Christians and helped in it. Finally the ancient Christian authors saw in the figure of the rooster a symbol of the preacher of the Gospel. The word of God should wake up „sleeping” or not overzealous Christians.

W drób dla mięsa i jaj, aby mieć koguty budzące ich o właściwej porze do pracy. W dobie obecnej być może nieco zapomniano, że kogut należy do specyficznego zbioru symboli, należącego nie tylko do chrześcijaństwa, lecz również do innych religii i kultur ${ }^{1}$.

\section{U źródeł chrześcijańskiej symboli koguta: świat antyczny, Biblia i judaizm}

W przeszłości kultura europejska chętnie łączyła koguta ze słońcem: swoim pianiem obwieszczał świt i odpędzał demony mroku². Czujność tego ptaka, jego ognistoczerwony grzebień, lśniące pióra uczyniły zeń atrybut bóstw słonecznych i zdrowia (Helios, Apollo, Atena, Asklepios). Dzięki waleczności ko-

1 Por. przede wszystkim J.P. Peters, The Cock, s. 363-396; G.N. Pintus, Storia di un simbolo: il gallo, s. 243-267; D. Forster, Świat symboliki chrześcijańskiej, s. 233-236; S. Kobielus, Bestiarium chrześcijańskie, s. 137-143; L. Charbonneau-Lassay, Le Bestiaire du Christ, s. 628-643; P. de Saint-Hilaire, Le coq.

2 Pianie koguta odstraszało także niezdrowe powietrze i nocne opary. 
gut znalazł się także przy boku bożka wojny Aresa (rzymski Mars) ${ }^{3}$. W starożytnej Grecji kogut symbolizował męską siłę witalną, oznaczał nieustanną wolę walki i rycerskość ${ }^{4}$, stąd był poświęcony bóstwom słonecznym odpowiedzialnym za płodność i urodzaj (Demetra) ${ }^{5}$. Przyrodnik Elian opisuje, że kogut był przyjacielem Latony, towarzysząc jej porodowi, gdy przyszło na świat „boskie rodzeństwo" - Apollo i Artemida ${ }^{6}$.

W pogańskiej Grecji uleczeni chorzy w ofierze składali Eskulapowi ${ }^{7}$ koguta. Tak nakazał uczynić po swojej śmierci filozof Sokrates ${ }^{8}$. Czyniono tak mimo maksymy pseudo - Pitagorasa: „Żywcie koguta, ale go nie składajcie w ofierze, ponieważ jest on poświęcony słońcu i księżycowi" ". Lekarze starożytni chętni polecali mięso lub rosół z tego ptaka na przeróżne dolegliwości. W starożytnym Rzymie $\mathrm{z}$ tego powodu, po jednej z epidemii umieszczono na kolumnie wizerunek koguta ${ }^{10}$. Pisarz rzymski Pliniusz Starszy uważa pianie koguta za dobrą wróżbę ${ }^{11}$. Wieszczkowie legionów rzymskich wróżyli dowódcom w czasie

3 Po gr. kogut to alektryon. W mitologii rycerz Alektryon był towarzyszem Aresa w nocnych pijatykach i potajemnych romansach. Gdy Ares spotykał się z żoną Hefajstosa, boginią Afrodytą, Alektryon alarmował kochanków, że już świta, że wschodzi słońce wszystkowidzący Helios i należy się czym prędzej ukryć. Na nieszczęście pewnej nocy zaspał i słońce zaskoczyło tę parę. Za karę wściekły Ares zmienił Alektryona w koguta, razem z jego hełmem, ostrogami i pióropuszem. Tak to powstał kogut, który po tej nauczce na zawsze już pozostał najbardziej czujnym z domowych ptaków i uważny był za opiekuna ludzi wcześnie wstających - kupców, pasterzy, żeglarzy. Por. Lukian, Gallus 3.

4 Por. Pauzaniasz, Periegesis VI 26, 3. Na temat walki kogutów w poezji greckiej i łacińskiej por. A. Sauvage, Étude de thèmes animaliers dans la poésie latine, s. 265-266.

5 Przykład stanowi relief z V w. przed Chr. z Locri (dziś w Reggio Calabria - Museo Nazionale della Magna Grecia); por. http://www.summagallicana.it/lessico/p/Proserpina\%20o\%20Persefone.htm (dostęp: 30.10.2011).

6 Por. De natura animalium IV 29. Por. Przykład monety z wyobrażeniem Ateny w hełmie korynckim i kogutem wg http://www.summagallicana.it/lessico/c/Cales.htm (dostęp: 30.10.2011).

7 Według mitologicznego podania Eskulap od centaura Chirona nauczył się sztuki wskrzeszania zmarłych. Kogut i wąż to emblematy medycyny i farmaceutyki.

8 „Kritonie, jesteśmy winni koguta Asklepiosowi! Oddaj go, a nie zapomnij!”; por. Platon, Phaedrus 118a. Kogut jako ptak życia w kultach starożytnych był ofiarowywany bogom zamiast ofiar ludzkich.

9 Na temat tej maksymy por. M. Timpanaro Cardini, Pitagorici. Testimonianze e frammenti, t. 3, s. 249 i 265. Wg legendy sam Pitagoras, nie pozwalał koguta zabijać ani jeść, gdyż ten upierzony na biało ptak był poświęcony Zeusowi.

10 Analogie można znależć również w ikonografii chrzecijańskiej (apostoł Piotr wyrzekający się Chrystusa).

11 Por. Historia naturalis X 21. 
kampanii wojennych z piania kogutów i z apetytu świętych kur. Były to ptaki chtoniczne i dlatego wróżebne ${ }^{12}$. Starożytności wyliczano i zauważano niemal wyłącznie same pozytywne cechy koguta. Wierzono, że ich piania obawiają się drapieżne zwierzęta, w tym lew i legendarny bazyliszek ${ }^{13}$. Nic więc dziwnego, że wyobrażenia koguta pojawiały się na biżuterii, tarczach i kamieniach nagrobnych. Ten piękny ptak to także częsty motyw rzymskich kompozycji mozaikowych ${ }^{14}$.

Pismo Święte nie idzie śladem starożytnego świata klasycznego, ale autorzy świętych ksiąg zwrócili uwagę na tak wspaniałe tworzenie Boże ${ }^{15}$. Kogut został sprowadzony do Palestyny zapewne z Indii. Niewykluczone, że stało się tak za sprawą słynnego króla Salomona, którego panowanie było okresem największego rozkwitu handlu i gospodarki starożytnego Izraela. Te przypuszczenia potwierdziły w pewnej mierze wykopaliska archeologiczne. Na terytorium Izraela Tell an-Nasbeh (biblijne Mispa) archeologowie znaleźli starożytną pieczęć z napisem „[należy do] Jaazadiaha, sługi królewskiego”. Na pieczęci wyryty jest kogut, stanowiący unikalny przykład tego typu ${ }^{16}$. Także w biblijnym Gibeonie odnaleziono przedmioty, na których figuruje podobizna koguta ${ }^{17}$.

W tłumaczeniach tekstów biblijnych nie zawsze istnieje zgodność co do określenia „kogut”. Grecka Septuaginnta (LXX) wspomina o tym ptaku tylko w Prz 30, 3, a wyklucza z Iz 22, 17 i Hi 38, 36 ${ }^{18}$. Z kolei wersja Wulgaty wymie-

12 Praktyki tego typu opisuje Liwiusz (VIII 30; IX 14; X 40) i Cyceron (por. De divinatione I 1, 1; I 4,7; II 3, 8; 5, 12; 10, 25; 20; 45; 34, 73). Por. również Petroniusz, Coena Trimalchionis, 74, 1-4; 78, 1-8; Swetoniusz, De vita Caesarum: Galba 18; Tiberius 2, 1; Vitellius 9,3.

13 Por. Elian, De natura animalium III 33; V 50; VIII 28. W II wieku w Aleksandrii gnostycy używali wizerunku Abraksasa z głową koguta, korpusem człowieka i wężowych kończynach. Por. P. de Saint-Hilaire, Le coq, s. 83; L. Charbonneau-Lassay, Le Bestiaire du Christ, s. 633.

14 Np. rzymska mozaika w I w. przed Chr. z „Burrel Collection” (Glasgow); II w. po Chr. z Poggio Mirteto (Włochy) oraz walka kogutów z Museo Archeologico Nazionale w Neapolu. Inne przykłady to mozaika podłogowa z Tunezji (III-V w.) w zbiorach Brooklyn Museum oraz z inskrypcją datowaną na 325-350 r. z Royal Ontario Museum. Por. http:// www.summagallicana.it/Emblemata/Arte/Mosaici (dostęp 05.11.2011).

15 Odnośnie do Starego Testamentu por. J.P. Peters, The Cock in the Old Testament, s. $152-156$.

16 Por. J.R. Zorn, Tell en-Nasbeh, w: E. Meyers (wyd.), The Oxford Encyclopedia of Archaeology in the Near East, t. 4, s. 102.

17 Por. B. Pritchard, The Water System of Gibeon (Museum Monographs), s. 20.

18 Por. A. Rahfls, Septuaginta; M. Harl- G. Dorival- O. Munnich, La Bible grecque des Septante. 
nia koguta we wszystkich trzech wersetach ${ }^{19}$. Współcześni egzegeci starali się wyjaśnić różnice $\mathrm{w}$ terminologii ornitologicznej tłumaczy biblijnych. W Nowym Testamencie wzmianki o kogucie dotyczą epizodu zaparcie się Chrystusa przez apostoła Piotra ${ }^{20}$.

Hiob, podziwiając dzieła Boże, wykrzykuje z podziwem: „Kto rozum dał kogutowi?” (Hi 38, 36) ${ }^{21}$. Pobożni Żydzi błogosławili każdego ranka Boga, który „dał rozum” temu pięknemu ptakowi ${ }^{22}$. Istotnie, trudno oprzeć się wrażeniu, że natura obdarzyła koguta swoistym instynktem. To ten ptak pełnił rolę prawdziwego stróża domu, godnego najwyższego podziwu ze względu na czujność i poczucia obowiązku. Domniemana mądrość koguta polegała także i na tym, że odróżniał on koniec nocy i początek dnia, swoim pianiem dając znać o tym całemu światu. Swoim stworzeniom Bóg daje instynkt, a królowi poparcie narodu, mówi autor księgi Przysłów: „Trzy rzeczy krok mają wspaniały, a cztery chód mają wyniosły: lew najdzielniejszy wśród zwierząt, przed niczym się nie cofa; kogut, co dumnie chodzi wśród kur; koń bojowy lub kozioł, i król, z którym jest lud [jego]" (Prz 30, 28-31). Kogut jawi się w tym tekście jako symbol dumy, a nawet siły. Rabini żydowscy nazywali koguta "geber" (samiec). W takim właśnie znaczeniu kogut pojawił się w tłumaczeniu Iz 22,17 u św. Hieronima: „Oto Pan pochwyci cię, tak jak się chwyta koguta”" ${ }^{2}$. Autor trzeciej księgi Barucha, przypisywanej uczniowi proroka Jeremiasza, tłumaczy, że kogut nigdy nie spóźnia się na spotkanie poranka, gdyż budzi go legendarny ptak Feniks - symbol zmartwychwstania. Tradycja żydowska i chrześcijańska posługują się wyrażeniem „o pianiu koguta” (łac. gallicinium), co znaczy bardzo wcześnie rano ${ }^{24}$.

Żydzi, jak widać, byli pełni podziwu dla wielorakich zalet i przymiotów boskich stworzeń. Jednak ważna rola koguta w kultach pogańskich wywoływała ich ostrą reakcję $e^{25}$. Według jednej z talmudycznych legend rozruchy, które doprowadziły do zniszczenia miasta Tur Malka, rozpoczęły się, gdy rzymscy

19 Por. R. Weber (red.), Biblia Sacra. Iuxta vulgatam versionem.

20 Por. Mt 26,34.75; Mk 14,30.68.72; Łk 22,34.60-61 i J 13,38; 18,27.

21 Por. F. Fedrizi (red.), La Sacra Bibbia: Giobbe, s. 264.

22 Por. Berakhoth 60b. Odnośnie do tego błogosławieństwa por. J.P. Peters, The Cock, s. $370-371,368$.

23 Dosłownie: Ecce Dominus asportari te faciet sicut asportatur gallus gallinacius.

24 „Pianie kogutów” było przysłowiowym wyrażeniem na oznaczenie wczesnej pory. Por. Alektrophonia, w: G.W.H. Lampe, A Patristic Greek Lexicon, s. 70.

$25 \mathrm{Na}$ temat koguta w tradycji judaistycznej por. L. Ginzberg et alii, Cock, w: Jewish Encyclopedia (wersja elektroniczna: www.jewishencyclopedia.com [dostęp: 03.10.2014]). 
legioniści rozpoczęli pochód ślubny z kurą i kogutem jako symbolami płodności ${ }^{26}$.

Odkryto ciekawy fakt w tradycji judaistycznej: przepisy rabinistyczne zabraniały hodowli drobiu w Jerozolimie, mimo faktu, iż nie chodziło przecież o ptactwo „nieczyste"27. Powodem było być może to, że hodowla kogutów mogłaby zaszkodzić czystości religijnej Żydów. Drobiazgowe przepisy rytualne były szczególnie ważne dla kapłanów pełniących służbę w świątyni Jerozolimskiej. „W Jerozolimie - czytamy w Misznie ${ }^{28}$ - nie wolno hodować kogutów, aby uniknąć skażenia zwierząt ofiarnych, i jest to zabronione kapłanom w całej Palestynie celem zachowania czystości" ${ }^{\prime 29}$. Wiadomo, że dokładne ustalenie czasu powstania powyższych tekstów jest prawie niemożliwe, trudno więc wyrokować, o tym czy tego typu surowych zakazów przestrzegano w czasach Chrystusa ${ }^{30}$.

W tradycji talmudycznej koguta uważano za mistrza grzeczności, ponieważ pianiem anonsował nadejście swojego pana - słońce ${ }^{31}$. Jest tu obecny element polemiki antychrześcijańskiej, bowiem kogut, który dostrzega pierwsze promienie brzasku, symbolizował wówczas nadejście oświecenia duchowego i przybycie Chrystusa - „Słońca sprawiedliwości”32.

26 Por. Talmud Babiloński, Gittin 57a.

27 Starożytna literatura żydowska wielokrotnie wspomina o tym zakazie. Por. np. Talmud Babiloński, Baba Qamd 82b.

28 To zbiór żydowskiego prawa ustnego, będący komentarzem prawniczym do Pięcioksięgu Mojżesza. Powstała ona około 200 r. po Chr. Księga ta stanowiła niewzruszony autorytet i stanęła u podstaw Talmudu jerozolimskiego (około 400 r. po Chr.) i Talmudu babilońskiego (około 500 r. po Chr.). Należy jednak zaznaczyć, że Miszna nie doczekała się do tej pory wydania krytycznego.

29 Talmud Babiloński, Baba Qamd 82b. Inny tekst powtarza ten sam zakaz i dodaje pewną ciekawą klauzulę: „Nie wolno hodować kogutów w Jerozolimie z obawy przed skażeniem zwierząt ofiarnych, chyba że posiada się ogród”; Tosefta, Baba Qamd 8,9. Tosefta zawiera tradycje żydowskie, które uzupełniają Misznę.

30 Kwestię źródeł judaistycznych i biblijnych ukazuje F. Manns, La faune biblique: Le coq, s. 98-101.

31 Por. S. Kobielus, Bestiarium chrześcijańskie, s. 138, przypis 7.

32 W starożytności często modlono się w kierunku wschodnim. U Hebrajczyków tego typu zwyczaj utrzymał się aż do czasów króla Salomona. U chrześcijan modlitwa skierowana na wschód stanowiła ważną i przestrzeganą praktykę. „Orientacja” wyrażała charakterystyczną dla chrześcijaństwa jedność pomiędzy wszechświatem a historią, nabierającą swego znaczenia w dziejach zbawienia. 


\section{Zwiastun dnia i zmartwychwstania}

Chrześcijanie widzieli w kogucie „zegar naturalny”, który przypomina o czasie na modlitwę i odpoczynek ${ }^{33}$, jak mówi przypisywana Hipolitowi Rzymskiemu (zm. 235 r.) Tradycja Apostolska ${ }^{34}$. Z kolei Tertulian zaprasza heretyka Marcjo$\mathrm{na}^{35}$ do przejścia ze sfery refleksji filozoficznej nad światem do konkretnych i prostych przykładów piękna stworzenia. Obok skromnego kwiatka i doskonałości form muszli jest mowa o lśniącymi piórze koguta ${ }^{36}$. Ten sposób ukazywania koguta w kategoriach piękna stworzenia będzie stałym motywem przepowiadania późniejszych autorów na temat księgi Rodzaju ${ }^{37}$.

Bazyli Wielki (zm. 379 r.) przypomina zalety światła dziennego, które zwiastuje pianie koguta: „Za dnia łatwiej spostrzec argumenty, dla których należy podziwiać Stwórcę. Patrz, jak kogut zachęca cię do pracy, pieje wyczuwając wcześniej, że dzień się zbliża. Nie wstaje później od podróżnych. Zachęca rolników do pracy przy żniwach"38. Niewątpliwie Kapadocczyk w swoich kazaniach korzystał z wzorów retoryki klasycznej ${ }^{39}$, wykazując jednocześnie znajomość realiów życia i natury ludzkiej oraz opisując w niezwykły sposób piękno otaczającego świata.

Wiadomo, że cykl kazań o Bazylego o dziele stworzenia zainspirował Ambrożego z Mediolanu (zm. 397 r. $)^{40}$. W homiliach o tym samym charakterze mówi on o tym, że „pianie koguta jest przyjemne w nocy; sprawia jednakże nie

33 Modlitwę poranną zwano gallicinum; por. B. Nadolski, Kogut, w: tenże, Leksykon liturgii, s. 482.

34 Traditio apostolica 41. Por. także Constitutiones apostolicae VIII,38.Św. Augustyn przekonywał, że pobozny człowiek rozpoczynał swój dzień od modlitwy; por. Enarrationes in Ps 118: Sermo 29,4.

35 Dzieło Przeciw Marcjonowi zajmuje centralną pozycję w obrębie dorobku literackiego i spekulatywnego Tertuliana. Por. J. Quasten, Patrologia, t. I, s. 516.

36 Por. Adversus Marcionem I, 13, 5.

37 Komentarze patrystyczne do Rdz wyliczają: J.P. Migne, Patrologia Latina cursus completus, t. 218, s. 931-938; F. Cavallera, Patrologia Graeca cursus completus - Indices, s. 144-145. Bogatą listę tekstów patrystycznych przedstawił Y. Congar, Le thème de DieuCréateur et les explications, s. 215-222. Por. również M. Conti - A. Louth, Genesis 1-11.

38 In Hexaemeron VIII,7. O etymologii słowa i znaczeniu „heksaemeron” por. Lampe, A Patristic Greek Lexicon, s. 140. Wyd. krytyczne homilii to S. Giet, Saint Basile de Césarée.

39 Jest to związane ze znajomością autorów klasycznych, takich jak Platon, Arystoteles i stoicy. Trwają dyskusje, w jaki sposób te eklektyczne przekonania zostały przekazane: w formie antologii, podręcznika, czy wypisów. Por. S. Zañartu, La Creación según el Hexaemeron de Basilio de Cesarea, s. 110-111.

40 Por. L.J. Swift, Basil and Ambrose on the Six Days of Creation, s. 317-328. 
tylko przyjemność, lecz jest pożyteczne. To dlatego, że jak dobry współmieszkaniec budzi tego, kto jeszcze drzemie, powiadamia tych, którzy się rozbudzili, dodaje otuchy podróżującym, [a czyni to] dając znać swoim dźwięcznym tonem, że noc dobiega kresu. Gdy słychać jego pianie, złoczyńca porzuca swoje zasadzki, a powstawszy, sama gwiazda poranna unosi się ku górze i rozjaśnia niebo. Na znak jego piania zatroskany żeglarz pozbywa się swoich zmartwień i każda zapowiedź burzy, którą wzbudzają często wiatry wieczorne, uspokaja się. Gdy słychać pianie koguta, pobożna dusza chętnie oddaje się modlitwie, a ponadto rozpoczyna na nowo przerwane czytanie" 41 . W tym przypadku jednak nie wzoruje się na wielkim Kapadocczyku, lecz tworzy oryginalną kompozycje literacką. Zwracając uwagę na opisy Ambrożego w Hexaemeronie, dostrzega się podobieństwo do hymnu Aeternae rerum conditor, gdzie w formie lirycznej biskup Mediolanu rozwija bogatą symbolikę koguta ${ }^{42}$. Ambroży był znanym i cenionym autorem hymnów liturgicznych, a w jego mowach poezja i proza ściśle się ze sobą splatają. Te proste w formie i metryce utwory są w pełni „poezją śpiewaną"43. Autor w prosty sposób, a jednocześnie elegancko i zwięźle, przedstawia treść teologiczną. Pięć pierwszych zwrotek rozwija symbolikę koguta jako zwiastuna słońca i jako Chrystusa -Światłość świata. To właśnie do Zbawiciela odnosi się wstęp hymnu: „Wieczysty rzeczy Stworzycielu, / Ty, który dniem i nocą rządzisz, / Ty, co odmieniasz pory czasu, / Aby nam ulżyć w trudach życia!”. Następnie autor odwołuje się do klasycznych motywów, opisując koguta jako czuwającego w nocy zwiastuna poranka oraz światło prowadzące w ciemnościach nocy ${ }^{44}$. Kolejne wersety hymnu ukazują zbawienne skutki piania koguta o poranku, które autor hymnu łączy ze znakiem danym Kościołowi i jego „Opoce” ${ }^{45}$ - apostołowi Piotrowi ${ }^{46}$. W typo-

\footnotetext{
41 In Hexaemeron V,24. Por. W. Szołdrski (tł.) - A. Bogucki (wstęp) - W. Myszor (opr.), Święty Ambroży. Hexaemeron.

42 Por. Pintus, Storia di un simbolo: il gallo, s. 261-263.

43 Hymny były układane we wpadającym w ucho dymetrze jambicznym, podzielonym na czterowierszowe zwrotki. Akcent słowny zgadzał się zazwyczaj z akcentem wierszowym. Por. M. Simonetti, Innologia Ambrosiana, s. 14-15 i 20-23.

44 „Już pieje dnia radosny zwiastun, / Który w głębokiej nocy czuwa. Światło wśród mroku dla wędrowców, Światło dzielące noc od nocy. / Wołaniem kura przebudzona / Jutrzenka nocny mrok rozprasza"; Aeternae rerum conditor 5-10. Przekład Z. Kubiaka w: (opr.) M. Starowieyski, Muza łacińska. Antologia poezji wczesnochrześcijańskiej i średniowiecznej (III-XIV/XV w.), s. 28-30.

45 Odnośnik do ewangelicznej metafory skały (por. Mt 16, 18) i do epizodu zaparcia się Jezusa przez Piotra (por. Mt 26,29-75; Mk 14,53-72; Łk 22,54-71; J 18,12-27).

46 „Cała zgraja błędnych duchów Przestaje ludziom czynić szkodę. / Żeglarz z otuchą ster ujmuje, / Fale się morza cichsze ścielą. / Słysząc wołanie kura, Kościół - / Opoka płacze grzechów swoich"; Aeternae rerum conditor 11-15.
} 
wym dla jego wrażliwości literackiej crescendo Ambroży zachęca: „Powstańmy teraz pełni mocy! / Już kur leżących ze snu budzi, / Woła, omdlałych napomina, / Tych, którzy przeczą, przekonuje”. Radosny „śpiew koguta” oznacza powrót nadziei, harmonii i ufności. W hymnie ambrozjańskim Chrystus określany jest jako „światłość” $(l u x)^{47}$. Jak kogut zwiastuje brzask i nadchodzący dzień, tak Chrystus ogłasza dzień zbawienia. To on otwiera umysły i rozprasza ospałość duszy ${ }^{48}$.

W konkluzji hymnu uwydatniony zostaje wymiar eklezjalny ${ }^{49}$ : „śpiew koguta" to śpiew całej ludzkości ${ }^{50}$. Oto rodzaj ludzki, wyprowadzony z mroków grzechu, rozpoczyna pieśń chwały: „Ty światłość jesteś. / O, zabłyśnij / Zmysłom i mroki duszy rozprosz! Ciebie niech sławi głos nasz pierwszy, Ciebie niech sławi pieśń ostatnia!" ${ }^{1}$. Ambroży od metafory „kogut - światło” przechodzi do rzeczywistości wiary Chrystus - Światłość. Również w hymnie przypisywanym Hilaremu z Poitiers „zwiastun jutrzenki” obwieszcza Chrystusa, Króla wieków ${ }^{52}$.

Chrześcijański poeta Prudencjusz (zm. po 405 r.) jest z całą pewnością kontynuatorem Ambrożego, chociaż wybiera własny styl liryczny ${ }^{53}$. Hymny Prudencjusza utworami poetyckimi przeznaczonymi do czytania. Jedną ze swoich Pieśni codziennych poświęca początkowi dnia obwieszczanemu pianiem

47 W Biblii to sam Bóg stosuje odnośnie do siebie język światła, które On sam stworzył przez swoje wszechmocne Słowo. Chrystus został nazwany przez starca Symeona „Światłem narodów” (Łk 2, 32): światłem, dzięki któremu wszystko nabiera sensu i w którym wszystko ma swoje miejsce. On jest phos hilaron, „radosnym Światłem świętej chwały Ojca Niebieskiego, Jezusa Chrystusa”, jak śpiewały pierwsze pokolenia chrześcijan.

48 „Powstańmy teraz pełni mocy! / Już kur leżących ze snu budzi, / Woła, omdlałych napomina, / Tych, którzy przeczą, przekonuje. / Nadzieja wraca z jego śpiewem i zdrowie krzepi ciała chore. / W pochwę się kryje miecz mordercy. / Kto zrozpaczony - znowu ufa"; Aeternae rerum conditor $17-24$.

49 Na temat oceny eklezjologii Ambrożego por. É. Lamirande, Saint Ambroise et le mystère de l'Église, s. 337-368. Opracowanie posiada bogatą bibliografię. Inne studia na ten temat to: B. Citterio, Lineamenti sulla concezione teologica della Chiesa, s. 54-63; G. Toscani, Teologia della chiesa in sant'Ambrogio; J. Moorhead, Ambrose: Church and Society in the Late Roman World.

50 Tematyka śpiewu zostala szeroko rozwinięta przez Ambrożego (por. np. Explanatio in Ps 1, 9). Por. P. Meloni, La chitarra di David, s. 258, 261.

51 Aeternae rerum conditor 29-32.

52 Por. Hymnus matutinus I, 1-7.

53 Prudencjusz wprowadza do utworów lirycznych element epicki, co było cechą Pindara. Na tym polega analogia między hymnami Prudencjusza a utworami tego wybitnego poety epoki klasycznej. 
koguta $^{54}$. Wersy Prudencjusza są przepełnione symboliką, a retoryka odgrywa w nich znaczną rolę ${ }^{55}$. Sen pojawia się jako symbol śmierci, a noc jako czas, w którym panują mroki grzechu i pokus, gdyż jest to pora działania złych duchów. Poeta chrześcijański zachęca żarliwie, aby obudzić się do nowego życia z grzesznego snu ${ }^{56}$. "Ptak, zwiastun dnia, zapowiada pianiem bliski brzask. / Nas przywołuje do życia, Ten który budzi dusze, Chrystus" ${ }^{57}$. Zbawiciel wzywa nas do światła wiary i życia: „Czyści, sprawiedliwi i trzeźwi czuwajcie, Ja jestem już blisko" ${ }^{2}$. Tak oto w symbolu koguta Prudencjusz dopatrzył się zapowiedzi Chrystusa, który wzywa do swego blasku: „To przedstawienie naszego Sędziego" 59 . Dalsze wersy mówią, że Chrystus powrócił z piekieł przy nocnym pianiu koguta, gdy „ten potrząsał skrzydłami”60. Natomiast Chrystus wzywa do swej światłości ${ }^{61}$. W pianiu koguta, zapowiadającym jutrzenkę, Prudencjusz dostrzegał jasno symbol i zmartwychwstania Chrystusa i nadziei powstania $\mathrm{z}$ martwych dla człowieka ${ }^{62}$. Zachowanie ptaka przypomina autorowi prawdę wiary, że Zbawiciel powrócił z piekieł przy pianiu koguta ${ }^{63}$. Myślą przewodnią jest wezwanie do obudzenia się do nowego życia z grzesznego snu. Na końcu hymnu poeta prosi: „O Chryste, otrząśnij nas ze snu! / Ty kruszysz okowy nocy, / niszczysz prastarą winę / i wlewasz nowe światło" ${ }^{64}$. Obok elementu lirycznego w hymnach Prudencjusza występuje także element pochwalny i parenetyczny. Celem poetyckich wersów zaś jest zachęcenie chrześcijan, by przez modlitwę pozyskiwali sobie łaski pochodzące od Boga ${ }^{65}$.

54 Księga (Cathemerinon) obejmuje 12 utworów. Sześć pierwszych odnosi się poszczególnych do pór dnia, a pieśni poranne są dwie. Hymny noszą tytuły: Ad galli cantum lub Ad gallicinium.

55 Odnośnie do kwestii stylu Prudencjusza por. przede wszystkim J.L. Charlet, La création poétique dans le Cathémérinon de Prudence; J.-P. Mazières, L’architecture symbolique des Cathémérinon de Prudence, s. 18-24.

56 Por. sumaryczne omówienei hymnu wg M. Cytowska - H. Szelest, Literatura rzymska. Okres cesarstwa. Autorzy chrześcijańscy, s. 198.

57 Cathemerinon I, 1-6. Tłum. własne. Znany jest przekład M. Brożka w: (opr.) M. Starowieyski, Muza łacińska, s. 50-54.

58 Cathemerinon I, 7-8.

59 Ibidem I, 16.

60 Ibidem I, 45.

61 W utworach Prudencjusza charakterystyczne jest, że powtarza się w nich w różnych ujęciach motyw światła i słońca, które są symbolami Chrystusa i Jego łaski.

62 To powód, dla którego umieszczano podobiznę koguta na płytach nagrobnych.

63 Por. Cathemerinon I, 65-72.

64 Cathemerinon I, 97-100.

65 Por. komentarze M.M. van Assendelft, Sol ecce surgit igneus. 
W kontekście gotowości i czuwania kogut występuje w nauczaniu Jezusa. Jego uczniowie bardzo chcieli poznać dokładny termin chwalebnego przyjścia Mesjasza. Wszystkich Jego wyznawców Chrystusa winna cechować czujność. "Czuwajcie więc, bo nie wiecie, kiedy pan domu przyjdzie: z wieczora czy o północy, czy o pianiu kogutów, czy rankiem. By niespodzianie przyszedłszy, nie zastał was śpiących" (Mk 13,35-36). Jego pianie zwiastuje wschód słońca, będzie też oznaczało powtórne przyjścia Chrystusa - „Słońca sprawiedliwości", nastanie Królestwa Bożego, sąd ostateczny i koniec świata ${ }^{66}$. W szeregach pierwszych chrześcijan nadzieja odnowy historii i perspektywa eschatologiczna były niezwykle żywotne ${ }^{67}$, co znajdowało swoje przełożenie w literaturze, ale także w ikonografii chrześcijańskiej. Wyobrażenie koguta na stałe weszło do ornamentyki ${ }^{68}$ i cyklów narracyjnych. Z coraz większą intensywnością symbolika koguta zostaje ukierunkowana na sylwetkę głoszącego słowo Boże i narzędzia ewangelizacji.

Użycie wyobrażenia koguta w ikonografii chrześcijańskiej może pochodzić z kultu perskiego bożka Mitry ${ }^{69}$. W Akwilei na terenie tzw. auli teodoriańskiej (w części północnej bazyliki) znajduje się kompozycja z walczącymi żółwiem $\mathrm{i}$ kogutem. Scena, z nielicznymi wariantami, powtarza się dwukrotnie. Interpretacja odwołuje się do walki dobra (symbolizuje je kogut) ze złem, reprezentowanym przez żółwia, jako posłańca podziemnej otchłani i sił demonicznych ${ }^{70}$. Sama scena jest unikalna w repertorium ikonografii chrześcijańskiej. Jak się wydaje, ma ona stanowić przypomnienie, że chrześcijanin powinien walczyć ze złem i w ten sposób osiągnie chwałę zmartwychwstania. Mozaika podłogowa z IV wieku w Akwilei to niezwykły przykład tego typu techniki na Zachodzie. Kompozycjom w Akwilei poświęcono bardzo wiele opracowań, dotyczących przede wszystkim ich znaczenia symbolicznego ${ }^{71}$. W kogucie można także do-

66 Czujny kogut jako pierwszy miał obwieścić światu narodziny Chrystusa, stąd w wierzeniach ludowych szczególną wagę przykładano do piania kogutów w noc bożonarodzeniową. Podobnie kogut, jako pierwszy, ma zapowiedzieć Paruzję.

67 Najlepiej udokumentowany nurt chrześcijańskich pojęć eschatologicznych stanowi milenaryzm. Por. W. Bauer, Chiliasmus, s. 1073-1078.

68 Liczne przykłady na mozaikach z terenu Zajordania (okres bizantyjski) wg M. Piccirillo, The Mosaics of Jordan, s. 290, 298; M. Piccirillo - J. Balty, I mosaici di Giordania, s. 226; S. Rollin - J. Streetly (red.), The Blue Guide to Jordan, (passim).

69 Zbieżność chronologiczna popularności kultu Mitry i rozwoju wczesnego chrześcijaństwa z pewnością nie jest bez znaczenia dla ikonografii. W mazdaizmie traktowano koguta jako ptaka solarnego. Natomiast pitagorejczycy rozpowszechnili jego kult w Rzymie i Grecji.

70 Por. http://www.summagallicana.it/lessico/a/Aquilea.htm (dostęp: 03.11.2011).

71 Por. M. Mirabella Roberti, Aquileia. I: Origine del cristianesimo, kol. 454. 
patrzeć się symbolu Chrystusa, który zwiastuje świt i swoje zmartwychwstanie, przez co przepędza żółwia - mieszkańca podziemia i symbol zła ${ }^{72}$.

\section{Kogut obwieszczający nadzieję upadłym}

$\mathrm{Na}$ kartach Ewangelii pianie koguta to przypomnienie trudnych chwil i upadku księcia apostołów ${ }^{73}$. Ewangelista Łukasz w zakończeniu opowiadania o wypadkach nocy pojmania i sądzenia Chrystusa, przywołuje znamienny szczegół: „W tej chwili..., kogut zapiał. A Pan obrócił się i spojrzał na Piotra. Wspomniał Piotr na słowo Pana, jak mu powiedział: «Dziś, zanim kogut zapieje, trzy razy się Mnie wyprzesz». Wyszedł na zewnątrz i gorzko zapłakał” (Łk 22, 60-62)74. Zarówno w zapowiedzi upadku Piotra apostoła, jak i w samym ewangelicznym opisie (Mk 14, 30.72) ${ }^{75}$, pianie koguta odgrywa kluczową rolę. Ma ono nie tylko znaczenie chronologiczne ${ }^{76}$, ale również stanowi wymowny symbol podniesienia się z upadku. Implicite ma się do czynienia także z antytezą czujności ptaka i grzesznego otępienia ucznia. Scena zaparcia się Piotra apostoła była często

72 Gr. tartarouchos, co daje łac. tartaruchum - czyli mieszkaniec Tartaru, świata podziemnego. Por. Lampe, A Patristic Greek Lexicon, s. 1396.

73 Ewangeliści mówiący o piejącym kogucie przy zaparciu się apostoła Piotra, pozwalają przypuszczać, że rabinistycznych zakazów hodowli drobiu nie przestrzegano zbyt rygorystycznie.

74 W odróżnieniu od św. Marka, który wspomina o dwukrotnym pianiu koguta, pozostali ewangeliści ograniczają się do zapowiedzi, iż Piotr zdradzi Jezusa „zanim kogut zapieje" (Mt 26, 34; Łk 22, 34; J 13, 38). Rozbieżność zauważyć można w opisie samej zdrady (por. (Mk 14, 68. 72; Mt 26, 74; Łk 22, 60; J 18, 27). Najprostszym sposobem na rozwiązanie sprzecznych ze sobą wersji byłoby opuszczenie Markowej wzmianki o pierwszym pianiu koguta. Takiej operacji dokonano we wielu współczesnych przekładach. Sposób wygodny, lecz nie do przyjęcia. Oznaczałoby to bowiem, że trudniejsza do zrozumienia relacja Marka mija się z prawdą. A w rzeczywistości jest ona po prostu relacją dokładniejszą. Drugi ewangelista jako jedyny sprecyzował - dzięki wzmiance o pierwszym i powtórnym pianiu koguta, że kolejne zaparcia się Piotra miały miejsce na początku i w końcowej fazie trzeciej straży nocnej, dając jasno do zrozumienia, że były one rozłożone w czasie. Por. G. Brunet, „Et aussitôt le coq chanta”, s. 9-12.

75 Onośnie do tego epizodu por. C. Lattey, A Note on Cockcrow, s. 53-55; H. Kosmala, The Time of the Cock-Crow, s. 118-120; 6 (1967-1968), s. 132-134; M. Wilcox, The Denial Sequence in Mark xiv. 26-31, 66-72, s. 426-436.

76 Typowy dla Żydów był podział nocy na trzy straże. Zastąpiono go jednak praktyką rzymską, zgodnie z którą porę nocną dzielono na cztery straże: wieczór (godz. 18.00-21.00), północ (godz. 21.00-00.00), pianie kogutów (godz. 00.00-3.00), ranek (godz. 3.00-6.00). Por. np. Mk 6,48. 
przedstawiana na starożytnych freskach, sarkofagach chrześcijańskich i mozai$\operatorname{kach}^{77}$. Kogut stał się stałym znakiem rozpoznawczym tego apostoła ${ }^{78}$. Epizod ten stanowił ostrzeżenie przed pychą i pouczenie o możliwości pokuty, a sama scena ewangeliczne stała się przedmiotem rozważań pisarzy starożytnego Kościoła ${ }^{79}$.

Uwagę zwracała relacja ewangelisty Marka ${ }^{80}$ odnośnie do epizodu wyparcia się Jezusa przez jego apostoła. Mówi Jan Chryzostom (zm. 407): "Należy podziwiać, że [święty Marek] nie przemilczał upadku nauczyciela, lecz wyraźniej niż inni o nim opowiedział" ${ }^{\text {. W }}$ W związku z tym epizodem ewangelicznym Złotousty nadmienia, że słowo Chrystusa jest niezawodne, natomiast odczucia ludzkie mają charakter przelotny i złudny ${ }^{82}$. Hilary z Poitiers natomiast zauważa, że Piotr wyparł się Chrystusa jako człowieka, a nie jako Syna Bożego $^{83}$.

Św. Ambroży, który szeroko rozwijał biblijne porównania związane z kogutem, pisze „[Gdy Chrystus] spojrzał na Piotra i od razu jego wina znikła, zostało oddalone jego zaparcie się [Pana] i przyszło wyznanie winy... Jest napisane: «Zanim kogut zapieje, trzy razy mnie się wyprzesz» (Mt 26,34). Pewny siebie za dnia, Piotr traci ducha, i zanim kogut pieje upada i to po trzykroć. To dlatego, abyś ty wiedział, że upadł on nie tylko z powodu niekontrolowanej wylewności w mówieniu, ale z powodu chwiejności swego ducha. Jednak, po tym, jak kur zapiał, staje się mocniejszy i godny tego, aby spojrzał nań Chrystus... Zrozumiał, że przyszło lekarstwo" ${ }^{44}$. Kogut obwieszcza nadzieję wszystkim cierpiącym na duszy i na ciele. Jednak w sposób szczególny Jezus zwrócił

77 Doliczono się blisko 70. tego typu scen. Por. U. Broccoli, Pietro, kol. 4075, bibliografia kol. 4076.

78 Najbardziej znane wyobrażenia tego typu to np. fresk z katakumb Komodylli (Rzym, IV w.) i mozaika ścienna z Sant’Apollinare Nuovo (Rawenna, VI w.).

79 Por. A. Fitzgerald, Christ, Peter and the rooster, s. 409-424.

80 Druga ewangelia nie wydawała się atrakcyjna dla komentatorów wczesnego chrześcijaństwa. Z nielicznymi wyjątkami była to niemalże „zapomniana księga”. Tylko św. Hieronim wygłosił cykl kazań o Mk, a pierwszy systematyczny komentarz zawdzięczamy Wiktorowi z Antiochii (V-VI wiek). Por. M. Cahill, The identification of the First Markan Commentary, s. 258-268.

81 Commentarii in Matth. 85. Por. J. Krystyniacki (tłum.) - E. Buszewicz (uwspółcześnienie tekstu) - A. Baron (rewizja, opr. i przyp.), Jan Chryzostom. Komentarz na Ewangelię według św. Mateusza. Część druga: homilie 41-90.

82 Por. ibidem 82.

83 Por. Commentarii in Matth. 32,4.

84 In Hexaemeron V,24. 
się do Piotra ${ }^{85}$, który się nawrócił: „Kiedy kur zapieje, sam Kamień (łac. Petra) Kościoła - Piotr, obmywa winę, którą popełnił przez zaparcie się [Pana], zanim kogut zapiał"86. Biskup Mediolanu postrzega sylwetkę duchową Księcia Apostołów w podwójnym aspekcie: przed i po pianiu koguta ${ }^{87}$. Piotr popełnia grzech zdrady, lecz post galli cantum staje się silny i godny miana apostoła. Ambroży prosi Chrystusa, aby prowadził ludzi do nawrócenia, udzielając im daru „Piotrowych łez”88. Sam kaznodzieja w sposób symboliczny przedłuża swoją homilię aż do czasu, gdy odezwie się „Mistyczny Kogut” (Chrystus), który przebacza grzechy i prowadzi człowieka na ścieżkach życia ${ }^{89}$.

Dramatyczne wydarzenia związane z zaparciem się Chrystusa przez apostoła wskazały na problem upadłych chrześcijan czyli tzw. „lapsi”, co miałyby sugerować słowa porannego hymnu ambrozjańskiego: „Spójrz, Jezu, na tych, co upadli. Spojrzeniem swoim nas podźwignij. Gdy na nas patrzysz, giną grzechy I we łzach wina się rozpływa"90. Ambroży nazywa Chrystusa Gallus mysticus, ponieważ jest zwycięzcą grzechu, śmierci i piekła. Zmartwychwstały o poranku Zbawiciel wzywa nieustannie do czynów światłości ${ }^{91}$.

Również poecie chrześcijańskiemu Prudencjuszowi pianie koguta przypomina Piotra, który wyparł się swego Mistrza, ale uznał swój grzech, za który żałował: „Grzech popełnia się, zanim zwiastun bliskiego światła / oświeci ród ludzki i położy kres występkowi"92.

W przekonaniu autorów starochrześcijańskich za przykładem Szymona Piotra wszyscy powinni usłuchać wezwania do powstania z grzechów, aby „chodzić w światłości Pana”. Do miejsca zaparcia się świętego Piotra nawiązywał Cyryl Jerozolimski (zm. 386 r.), ostrzegając: „Jeśli się zaprzesz [krzyża

85 Por. także Hieronim ze Strydonu, Commentarii in Matth. IV, 1.

86 In Hexaemeron V, 24. Ambroży analizuje winę Piotra apostoła także w Explanatio Ewangelii secumdum Lc X, 72-92.

87 Por. Pintus, Storia di un simbolo: il gallo, s. 264-266.

88 In Hexaemeron $\mathrm{V}, 24$.

89 Por. In Hexaemeron V, 24. Odnośnie do tej analizy por. G.N. Pintus, Storia di un simbolo, s. 265-266.

90 Aeternae rerum conditor 25-28.

91 Por. B. Nadolski, Kogut, s. 645.

92 Cathemerinon I, 55-56. 
Chrystusowego]..., niech cię upomni dom Kajfasza ${ }^{93}$, który obecną swoją ruiną wskazuje na potęgę Tego, który tutaj został osądzony"94.

Związek wizerunku koguta ze znanym i komentowanym fragmentem Ewangelii spowodował, że często przedstawiano na mozaikach i lampkach oliwnych. Te ostatnie przedmioty przypominały o potrzebie czuwania i pomagały w nim. Pianie koguta kojarzono z trzecią strażą nocną, a więc z najwcześniejszymi godzinami rannymi (od drugiej do szóstej). Kogut stał się zwiastunem nadziei, gdyż jak mówi Ambroży, w chwili jego piania „powraca do wszystkich nadzieja, męki stają się lżejsze, uśmierza się ból ran, osłabia się żar gorączki, a ten, kto upadł napełnia się ufnością" (O stworzeniu świata $\mathrm{V}, 24)$. W epoce nowożytnej książę apostołów - święty Piotr, z nieodłącznym kogutem, stał się patronem zegarmistrzów. W świątyniach używano też lamp w kształcie koguta. Miały przypominać wiernym o potrzebie czujności wobec rychłego przyjścia Pana ${ }^{95}$.

\section{Symbol głoszących słowo Boże}

W schyłkowej fazie okresu patrystycznego symbol koguta został przewartościowany i symbolizował już nie Chrystusa, ale jego sługę. Dla Eucheriusza kogut to odpowiednik świętych ${ }^{96}$, a dla średniowiecza wskazywał na kapłanów. Raban Maur pisał, że kogut oznacza męża świętego albo ewangelicznego mędrca, który żyjąc w ciemności tego świata, głosi światło życia wiecznego ${ }^{97}$.

93 W Jerozolimie istnieje kościół św. Piotra In galli cantu. Tak więc kogut związany ze zdradą apostoła Piotra jest bodajże jedynym przedstawicielem fauny, który może się poszczycić tego typu miejscem. W wielopoziomowym współczesnym sanktuarium znajduje się grota służąca w starożytności jako miejsce kultu, na co wskazują krzyżyki bizantyjskie namalowane na ścianach i resztki mozaik. Pielgrzymom chrześcijańskim miejsce to zaczęło się kojarzyć z terenem dawnego pałacu Kajfasza. W ten sposób grotę utożsamiono z „więzieniem Jezusa”, a pobliskie zagłębienia skalne z cichym ustroniem, gdzie Piotr opłakiwał zdradę swego Mistrza. Por. Pictorial Guide to Saint Peter in Gallicantu, [s.d.].

94 Catechesis X, 19. Por. (wst.) J. Bojarski - (tłum.) - W. Kania, Św. Cyryl Jerozolimski. Katechezy przedchrzcielne i mistagogiczne.

95 Por. P. Idziak, Kurek na wieży - zwiastun końca świata; http://www.wioskitematyczne.org.pl (dostęp 04.10.2014).

96 Por. Formulae 4.

97 Por. De universo VI. 
Papież Grzegorz Wielki (zm. 604 r. $)^{98}$ w Regule pastoralnej porównuje zalety koguta z cechami, które powinien posiadać, ten kto głosi prawdy Ewangelii. „Błogosławiony Hiob powiedział: «Kto rozum dał kogutowi?» (Hi 38,36). W rzeczywistości święty kaznodzieja, który woła w tym mrocznym czasie, jest jak kogut piejący w nocy. Wtedy rzecze: «Nadeszła dla was godzina powstania ze snu» (Rz 13,11) i jeszcze: «Ocknijcie się i przestańcie grzeszyć» (1 Kor 15,34). Lecz zwykle kogut wydobywa z siebie głośnie pianie w porze głębokiej nocy, natomiast, gdy godzina poranna jest coraz bliżej, wtedy pieje łagodniej i lżej. Dzieje się tak dlatego, że przepowiadający woła w sposób jasny i zrozumiały do serc, które pozostają jeszcze pogrążone w mrokach i nie wspomina o ukrytych tajemnicach, aby [wierni] byli w stanie słuchać mów bardziej przenikliwych o rzeczach niebiańskich, kiedy zbliżają się do światła prawdy" 99 . Te i podobne wskazania pokazują wysokie mniemanie, jakie papież Grzegorz Wielki miał o duszpasterstwie, które określał mianem najwyższej ze sztuk (ars artium) ${ }^{100}$.

Papież podaje ten przykład także dlatego, że „zanim zabrzmią słowa napomnienia, niech najpierw wołają czyny, o tym, co ma być powiedziane". Oto przyczyny dla których, także i w tym przypadku, symbol koguta posiada swoją wymowę: „Potrząsa [on] skrzydłami i uderzając w siebie samego, rozbudza się... Jest konieczne, aby rozpoczynający święte przepowiadanie sami najpierw czuwali i oddawali się czynieniu dobra. Niech nie uważają, że poruszą innych słowami, gdy oni sami śpią bezwładni" ${ }^{101}$. Potrząsanie skrzydłami przez kogu$\mathrm{ta}^{102}$ znajduje swoje metaforyczne wytłumaczenie. Zabieg ten miał go uczynić jeszcze czujniejszym. Podobną gotowością miało cechować się życie ewangelizatorów, którzy zanim zaczną nauczać, sami muszą ćwiczyć się w ascezie, by potem pobudzać innych do doskonalszego życia ${ }^{103}$. Odnośnie do upierzenia koguta Grzegorz Wielki zwraca uwagę, że wygląda on jakby miał przepasane lędźwie, co wskazuje na opanowanie kaznodziejów w sferze popędów, których

98 Na temat tego autora istnieje spora literatura przedmiotu; por. R. Godding, Bibliografia di Gregorio Magno. 1890/1989, Rzym 1990.

99 Regula pastoralis III, 39.

100 Por. L. La Piana, Teologia e ministeri della parola in S. Gregorio Magno.

101 Regula pastoralis III, 40.

102 Tego typu motyw dotyczący koguta miał swoje odpowiedniki religijności perskiej. W przekonaniu Persów kogut miał wstrząsać leniwymi i wzywać ich do porannej modlitwy, jak również odpędzać złe duchy, ponieważ zapowiadał światło słoneczne, które rozprasza nocne duchy. Por. Nadolski, Kogut, s. 645.

103 Pisma Grzegorza Wielkiego były bardzo popularne w średniowieczu. O podobnych wątkach u autorów średniowiecznych por. S. Kobielus, Bestiarium chrześcijańskie, s. 139, przypis 16. 
siedliskiem są właśnie lędźwie ${ }^{104}$. Komentarz moralny do Hioba stanowił w późniejszej epoce swego rodzaju summę chrześcijańskiej moralności. Średniowiecze przejęło wymowne porównanie koguta do kaznodziei, który przez przepowiadanie słowa Bożego winien budzić „drzemiących” czyli niezbyt gorliwych chrześcijan ${ }^{105}$. Autorzy średniowieczni ukazywali, że noc to obecny świat, a nowym dniem jest królestwo Boże.

Kogut pojawił się już na szczytach dzwonnic romańskich kościołów jako symbol obwieszczający światło i wzywający do porannej modlitwy. Kurki na wieżach kościelnych były zakładane od IX w., początkowo we Włoszech, w Brescji i w Rzymie, oraz w Anglii (katedra w Winchester). Do dziś w niektórych krajach zachowano ten zwyczaj ${ }^{106}$.

\section{Bibliografia}

Bauer W., Chiliasmus, w: Reallexikon für Antike und Christentum, Th. Klauser (red.), t. 2, Stuttgart 1954, s. 1073-1078.

Bojarski J. (wst.) - Kania W. (tłum.), Św. Cyryl Jerozolimski. Katechezy przedchrzcielne i mistagogiczne (Biblioteka Ojców Kościoła, 14), Kraków 2000.

Broccoli U., Pietro, w: Nuovo dizionario patristico e di antichità cristiane, Di Berardino A. (red.), t. 3, Genua - Mediolan 2008, kol. 4075, bibliografia kol. 4076.

Brożek M., Prudencjusz Aureliusz Klemens. Poezje, tłum., wstęp i opr., (Pisma Starochrześcijańskich Pisarzy 43), Warszawa 1987.

Brunet G., "Et aussitôt le coq chanta", Cahiers du Cercle E. Renan 27 (1979), s. 9-12.

Cahill M., The identification of the First Markan Commentary, RB 101/2 (1994), s. 258268.

Calati B., La lettura di Giobbe secondo Gregorio Magno. Le provocazioni di Giobbe. Una figura biblica nell'orrizonte letterario, Genua 1992.

Cavallera F., Patrologia Graeca cursus completus - Indices, Paryż 1912.

Charbonneau-Lassay L., Le Bestiaire du Christ, Paryż 2006.

Charlet J.L., La création poétique dans le Cathémérinon de Prudence, Paryż 1982.

Citterio B., Lineamenti sulla concezione teologica della Chiesa, w: Sant'Ambrogio nel XVI centenario dalla nascita, Mediolan 1940, s. 54-63.

104 Por. Moralia in Job XXX, 1. 17-19; B. Calati, La lettura di Giobbe secondo Gregorio Magno, s. 55-63.

105 Honoriusz z Autun nawiązywał do tego wizerunku koguta i w jego porannym pianiu upatrywał wezwanie do chwalenia Boga. Por. Gemma animae I, 144. Inny znaczący przykład wg Libellus de natura animalium, s. 218-221.

106 Por. J. Hani, Symbolika świątyni chrześcijańskiej, s. 77-78. 
Congar Y., Le thème de Dieu-Créateur et les explications de l'hexaméron dans la tradition chrétienne, w: L’homme devant Dieu. Mélanges offerts au H. de Lubac, t. 1, Paryż 1963, s. 215-222.

Conti M. -Louth A., Genesis 1-11 (Ancient Christian Commentary on Scripture: Old Testament I), Grand Rapids 2001.

Cytowska M. -Szelest H., Literatura rzymska. Okres cesarstwa. Autorzy chrześcijańscy, Warszawa 1994

de Saint-Hilaire P., Le coq, Paryż 2007.

Fedrizi F. (red.), La Sacra Bibbia: Giobbe, Turyn-Rzym 1972.

Fitzgerald A., Christ, Peter and the rooster, Augustinianum 41/2 (2001), s. 409-424.

Forster D., Świat symboliki chrześcijańskiej, Warszawa 1990.

Giet S., Saint Basile de Césarée. Homélies sur l'Hexaéméron: texte grec, introduction et traduction (SC [= Sources Chrétiennes] 26 bis), Paryż 1968².

Ginzberg L. et alii, Cock, w: Jewish Encyclopedia (wersja elektroniczna: www.jewishencyclopedia.com [dostęp: 03.10.2014]).

Godding R., Bibliografia di Gregorio Magno. 1890/1989, Rzym 1990.

Hani J., Symbolika świątyni chrześcijańskiej, Kraków 1994.

http://www.summagallicana.it/lessico (dostęp: 30.10.2014).

Idziak P., Kurek na wieży - zwiastun końca świata; http://www.wioskitematyczne.org. pl (dostęp 04.10.2014).

Kobielus S., Bestiarium chrześcijańskie. Zwierzęta w symbolice i interpretacji: starożytność i średniowiecze, Warszawa 2002.

Kosmala H., The Time of the Cock-Crow, Annual of the Swidish Theological Institute 2 (1963), s. 118-120; 6 (1967-1968), s. 132-134.

Krystyniacki J. (tłum.) - E. Buszewicz (uwspółcześnienie tekstu) - A. Baron (rewizja, opr. i przyp.), Jan Chryzostom. Komentarz na Ewangelię według św. Mateusza.

Część druga: homilie 41-90 (Źródła Myśli Teologicznej 23), Kraków 2001.

La Piana L., Teologia e ministeri della parola in S. Gregorio Magno, Palermo 1987.

Lamirande É., Saint Ambroise et le mystère de l'Église. Questions et réflexions à propos d'un ouvrage récent, Église et Théologie 8 (1977), s. 337-368.

Lampe G.W.H., A Patristic Greek Lexicon, Oxford 1961.

Lattey C., A Note on Cockcrow, Scripture 6 (1953), s. 53-55.

Manns F., La faune biblique: Le coq, La Terre Sainte 4 (1977), s. 98-101.

Mazières J.-P., Larchitecture symbolique des Cathémérinon de Prudence, Vita Latina 113 (1989), s. 18-24.

Meloni P., La chitarra di David, Sandalion 5 (1982), s. 233-261.

Migne J.P., Patrologia Latina cursus completus, t. 218, Paryż 1865.

Mirabella Roberti M., Aquileia. I: Origine del cristianesimo, w: Di Berardino A. (red.), Nuovo dizionario patristico e di antichità cristiane, t. 1, Genua-Mediolan 2008.

Moorhead J., Ambrose: Church and Society in the Late Roman World (The Medieval World series), Londyn-Nowy Jork 1999.

Nadolski B., Leksykon liturgii, Poznań 2006.

Navone P. (opr.) et alii, Le proprietà degli animali, Genua 1983. 
Paczkowski M.C., Kogut - zwiastun brzasku i zmartwychwstania, Głos św. Franciszka 44/4 (2002), s. 40-42.

Paczkowski M.C., Kogut obwieszczajacy nadzieję i symbol głoszacych słowo Boże, Głos św. Franciszka 44/5 (2002), s. 36-39.

Peters J.P., The Cock in the Old Testament, JBL 33 (1914), s. 152-156.

Peters J.P., The Cock, Journal of the American Oriental Society 33 (1913), s. 363-396.

Piccirillo M. -Balty J., I mosaici di Giordania, Severino 1986, s. 226; S. Rollin - J. Streetly (red.), The Blue Guide to Jordan, Nowy Jork 1991.

Piccirillo M., The Mosaics of Jordan (American Center for Oriental Research [ACOR]), Amman 1993.

Pictorial Guide to Saint Peter in Gallicantu, Jerusalem [s.d.].

Pintus G.N., Storia di un simbolo: il gallo, Sandalion 8-9 (1985-1986), s. 243-267.

Pritchard B., The Water System of Gibeon (Museum Monographs), Pennsylvania 1961.

Quasten J., Patrologia, t. I, Casale Monferrato 1983 [dodruk], s. 516.

Rahfls A., Septuaginta, Stuttgart 1935; M. Harl- G. Dorival- O. Munnich, La Bible grecque des Septante, Paryż 1988.

Sauvage A., Étude de thèmes animaliers dans la poésie latine. Le cheval - les oiseaux (Coll. Lat. 143), Paryż 1975.

Simonetti M., Innologia Ambrosiana, Alba 1956.

Siniscalco P., opr., Gandolfo E., tłum., San Gregorio Magno. Commento morale a Giobbe (XXVII-XXXV), Rzym 2001.

Starowieyski M. (opr.), Muza łacińska. Antologia poezji wczesnochrześcijańskiej i średniowiecznej (III-XIV/XV w.) (Biblioteka Narodowa, seria II nr 255), Wrocław - Warszawa - Kraków 2007.

Starowieyski M. wstęp i opr., Szwarcenberg-Czerny E. tłum., Grzegorz Wielki. Księga reguły pasterskiej, List synodalny (1,24), Homilia 1,17, List 1,41 A (Źródła Monastyczne 30), Kraków 2003.

Swift L.J., Basil and Ambrose on the Six Days of Creation, Augustianum 21/2 (1981), s. 317-328.

Szołdrski W. (tł.) -Bogucki A. (wstęp) - W. Myszor (opr.), Święty Ambroży. Hexaemeron (Pisma Starochrześcijańskich Pisarzy 4), Warszawa 1969.

Timpanaro Cardini M., Pitagorici. Testimonianze e frammenti, t. 3, Florencja 1964.

Toscani G., Teologia della chiesa in sant'Ambrogio (Vita e Pensiero), Mediolan 1974.

van Assendelft M.M., Sol ecce surgit igneus. A Commentary on the Morning and Evening Hymns of Prudentius (Cath. 1; 2; 5 and 6), Groningen 1976.

Weber R. (red.), Biblia Sacra. Iuxta vulgatam versionem, Stuttgart 1975.

Wilcox M., The Denial Sequence in Mark xiv. 26-31, 66-72, New Testament Studies 17 (1970-1971), s. 426-436.

Zañartu S., La Creación según el Hexaemeron de Basilio de Cesarea, Teología y Vida 22 (1981), s. 110-121.

Zorn J.R., Tell en-Nasbeh, w: wyd. E. Meyers, The Oxford Encyclopedia of Archaeology in the Near East, t. 4, Nowy Jork-Oxford 1997. 